\title{
Morphological diversity of foliar trichomes in Asteraceae from Sand- fields of the Pampa biome, Rio Grande do Sul State, Brazil
}

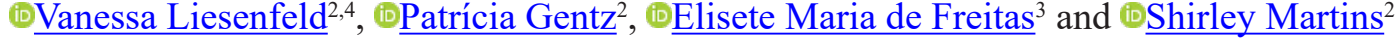

Received: 10 August 2018; accepted: 19 August 2019

How to cite: Liesenfeld, V., Gentz, P., Freitas, E.M. \& Martins, S.M. 2019. Morphological diversity of foliar trichomes in Asteraceae from Sand-fields of the Pampa biome, Rio Grande do Sul State, Brazil. Hoehnea 46: e752018. http://dx.doi. org/10.1590/2236-8906-75/2018.

ABSTRACT - (Morphological diversity of foliar trichomes in Asteraceae from Sand-fields of the Pampa biome, Rio Grande do Sul State, Brazil). Asteraceae is the largest family of angiosperms and occurs predominantly in grassland areas. This study aimed to identify and characterize the foliar trichomes of 34 Asteraceae species from Sand-fields of the Pampa biome, by means of epidermal analyzes (front and transverse view) under light and scanning electron microscopy. Eleven types of trichomes were identified and characterized: three glandular (recurved on the epidermis, erect-capitate and uniseriate to multiseriate vesicular-capitate) and eight non-glandular (simple conical, flagellate-filiform, aseptate-flagellate, whip-like, oblique-flagellate, branched with one arm, branched with two T-shaped arms, branched with three or more arms). The most representative glandular type was the uniseriate to multiseriate vesicular-capitate (58\%) and the non-glandular type was the simple conical (35\%). A large number of trichomes is an adaptive strategy to the adverse conditions of the Pampa biome and its morphological diversity can be useful in the family systematics.

Keywords: anatomical adaptations, glandular trichomes, leaf anatomy, non-glandular trichomes, taxonomy

RESUMO - (Diversidade morfológica de tricomas foliares em Asteraceae dos Campos de Areais do bioma Pampa, Estado do Rio Grande do Sul, Brasil). Asteraceae é a maior família das angiospermas e ocorre predominante em áreas campestres. Este estudo buscou identificar e caracterizar os tricomas foliares de 34 espécies de Asteraceae dos Campos de Areais do bioma Pampa por meio de análises da epiderme (vista frontal e transversal) em microscopia de luz e eletrônica de varredura. Foram identificados e caracterizados 11 tipos de tricomas: três glandulares (recurvado, capitado ereto e capitado vesicular unisseriado a multisseriado) e oito tectores (cônico simples, filiforme-flagelado, asseptado-flagelado, forma de chicote, oblíquo-flagelado, ramificado com um braço, ramificado com dois braços em forma de $\mathrm{T}$, ramificado com três ou mais braços). O tipo de tricoma glandular mais representativo foi o capitado vesicular unisseriado a multisseriado (58\%) e o tipo não glandular (tector) foi o cônico simples (35\%). A grande quantidade de tricomas é uma estratégia adaptativa às condições adversas do bioma Pampa e a sua diversidade morfológica pode ser útil na sistemática da família.

Palavras-chave: adaptações anatômicas, anatomia foliar, taxonomia, tricomas glandulares, tricomas tectores

\section{Introduction}

Asteraceae is the largest of the angiosperm families, with approximately 23,000 species distributed in over 1,600 genera, 13 subfamilies and 44 tribes (Funk et al. 2009, Panero et al. 2014). Its representatives are predominantly herbaceous, with simple and usually lobed leaves, inflorescence of the capitulum type and fruit of the cypsela type, which, along with the pappus, characterize its unit of dispersion (Roque \& Bautista 2008, Funk et al. 2009). In Brazil there are 2,100 species, 290 genera and 28 tribes of the family (Flora do Brasil 2020), with Vernonieae, Eupatorieae, Heliantheae, Astereae,

1. Parte da Dissertação do primeiro Autor

2. Universidade Estadual do Oeste do Paraná, Centro de Ciências Biológicas e da Saúde, Rua Universitária, 2069, Jardim Universitário, 85819-110 Cascavel, PR, Brasil

3. Universidade do Vale do Taquari, Laboratório de Botânica, Av. Avelino Talini, 171, Bairro Universitário, 95914-014 Lajeado, RS, Brasil

4. Corresponding author: vane_lie@hotmail.com 
and Gnaphalieae being the richest tribes according to floristic surveys of the family in some localities (Nakajima \& Semir 2001, Almeida et al. 2005, Ritter \& Baptista 2005, Heiden et al. 2007, Beretta et al. 2008, Fernandes \& Ritter 2009, Borges et al. 2010).

Asteraceae is one of the most successful plant families, because of the great diversity of secretory structures, the specialized methods of pollination and dispersion and phenotypic plasticity that contribute to the high number of species and their distribution in almost all habitats and vegetation formations (Smiljanic 2005, Beretta et al. 2008). However, a greater occurrence of the family is observed in open and arid areas (grasslands and savannas) and of high altitude and, less commonly, in forest environments (Barroso et al. 1991, Anderberg et al. 2007).

In Brazil, Asteraceae is distributed predominantly in the grassland formations of the Pampa biome (Ritter \& Baptista 2005, Cancelli et al. 2007), which in the country is restricted to the State of Rio Grande do Sul and presents mixed vegetation of grassland formations and forests, with a predominance of grasslands (Overbeck et al. 2007). In addition, the Pampa biome presents different phytophysiognomic units (Seasonal Forest, Central Fields, Barba-debode Fields, Deep-soil Fields, Savannoid Vegetation, Coastal Fields, Sand-fields, Parkland Vegetation, Shallow Soils and other formations) (Boldrini et al. 2010), among which the Sand-fields (southwest of the State) are distinguished by the high species richness of Asteraceae (77 spp.) in relation to the other families, being Astereae (17), Eupatorieae (12), Gnaphalieae (10) and Vernonieae (nine) the most representative tribes (Freitas et al. 2010).

The high representativeness of Asteraceae in the Sand-fields is possibly a result of the morphoanatomical adaptations of these plants, which allow their survival under extreme and limiting local environmental conditions such as sandy and low-fertility soils, water deficit, strong winds, high temperatures and high luminosity (Azevedo \& Kaminski 1995, Klamt \& Schneider 1995, Marchiori 1995, Freitas et al. 2009, 2010, Overbeck et al. 2015). These adaptations, usually xeromorphic, involve the presence of narrow leaves to reduce the surface area exposed to sunlight, presence of xylopodia and/or thick subterranean organs, presence of secondary metabolites to protect against predation, and a large number of trichomes on the vegetative organs (Lindman \& Ferri 1974, Boldrini 2009).
Trichomes have a fundamental role in protection against high temperatures, excessive light, pathogens and herbivores (Werker 2000, Wagner et al. 2014). In addition, they are one of the most useful characters used in taxonomic studies of many angiosperms due to their almost universal presence among taxa, easy observation and morphological diversity (Faust \& Jones 1973, Payne 1978, Adedeji \& Jewoola 2008, Krak \& Mráz 2008).

Trichomes can occur on vegetative and reproductive organs, varying in type and density over all parts of the plant and across different taxonomic levels (Werker 2000, Adedeji \& Jewoola 2008). Due to the high diversity of forms, sizes, functions, modes, and types of secretion, the classification of trichomes is wide, and the distinction between glandular (secretory) and non-glandular trichomes (non-secretory) is one of the most widely used categorizations (Werker 2000, Evert 2007, Krak \& Mráz 2008, Wagner et al. 2014).

Studies of trichomes began with Solereder (1908) and continued under other researchers in different families of angiosperms (Hemenway \& Allen 1936, Heintzelman \& Howard 1948, Metcalfe \& Chalk 1950, Metcalfe 1960, Ramayya 1962, Aleykutty \& Inamdar 1980). In the family Asteraceae, although the number of species and variety of trichomes is great, few studies have been carried out to know about these structures (Saha \& Mukherjee 2012, Arunprakash et al. 2014, Perveen et al. 2016).

Among the studies with trichomes in Asteraceae, we highlight those performed for the family as a whole developed by Carlquist (1961), Ramayya (1962), Saha \& Mukherjee (2012), Arunprakash et al. (2014) and Perveen et al. (2016). On the other hand, some studies with a focus on taxonomic levels below family stand out: Carlquist (1958) for the subtribe Madinae; Narayana (1979) for the genus Vernonia; Krak \& Mráz (2008) for the tribe Lactuceae; Hayat et al. (2009) for the genus Artemisia; Redonda-Martínez et al. (2012) for the genera Vernonanthura and Vernonia; Sulborska (2013) for the species Inula helenium L.; Trindade et al. (2014) for the species Lomatozona artemisiifolia Baker; Wagner et al. (2014) for the subtribe Lychnophorinae; Fernandes et al. (2016) for the species Trichogonia cinerea (Gardner) R.M. King \& H. Rob.; Redonda-Martínez et al. (2016) for the subtribe Leiboldiinae and Rojas-Leal et al. (2017) for the genus Senecio section Mulgediifolii.

Considering the ecological importance of trichomes and representativeness of Asteraceae in the 
Sand-fields of Rio Grande do Sul (important area for conservation of native vegetation), this study aimed to identify and characterize the foliar trichomes observed in the species of the family occurring in this place, contributing to the knowledge of these structures and supporting taxonomic work in the Asteraceae family.

\section{Material and methods}

The 34 Asteraceae species studied (table 1) were collected in the southwestern region of Rio Grande do Sul - Brazil, in the municipalities of Alegrete, Manoel Viana and São Francisco de Assis (between latitudes $29^{\circ} 00^{\prime} \mathrm{S}$ and $31^{\circ} 00^{\prime} \mathrm{S}$ and longitudes $54^{\circ} 30^{\prime} \mathrm{W}$ and $58^{\circ} 45^{\prime} \mathrm{W}$ ), in areas of natural grasslands of sandy soils susceptible to the sandy patch process, with or without influence of livestock activity (Freitas et al. 2010).

In this region the climate is humid subtropical (Moreno 1961) with an average annual rainfall of $1400 \mathrm{~mm}$ (Nimer 1979); however, rains are poorly distributed, with periods of reduced rainfall interspersed with heavy rains that can concentrate rain in just one day (Freitas et al. 2009). Due to high evaporation, periods of water deficit can occur (Berlato et al. 2006). The mean annual temperature is $14.3{ }^{\circ} \mathrm{C}$ in winter and $26.3{ }^{\circ} \mathrm{C}$ in summer (Nimer 1979), although absolute minima and maxima are $-4{ }^{\circ} \mathrm{C}$ and $40{ }^{\circ} \mathrm{C}$, respectively (Cordeiro \& Soares 1977).
The relief, originating from the Botucatu sandstone formation, is gently undulating punctuated with flat areas. The soil is Ortic Quartzarenic Neosol (Streck et al. 2008), with arenous and silty-arenous texture, high acidity, phosphorus and potassium deficiency, an excess of aluminum and difficulty in water retention (Azevedo \& Kaminski 1995, Klamt \& Schneider 1995, Verdum 2004). These characteristics reduce its fertility, making it highly susceptible to erosion and water scarcity in periods of drought (Azevedo \& Kaminski 1995, Klamt \& Schneider 1995).

The collections were carried out in the months of May, October and December 2016 and in February and May 2017. Fertile individuals were herborized and deposited in the collection of the UNOP Herbarium of the Universidade Estadual do Oeste do Paraná Cascavel campus (table 1). The specimens were identified through comparison with the samples deposited in the herbarium ICN of the Universidade Federal do Rio Grande do Sul and herbarium of the Universidade do Vale do Taquari and by specialists (Gustavo Heiden, Mara Angelina Galvão Magenta, Eduardo Pasini and Roberto Lourenço Esteves).

For the analysis of leaf epidermis in frontal view in scanning electron microscopy (SEM), portions of the median region of fully expanded leaves were fixed in $2.5 \%$ glutaraldehyde, washed in phosphate buffer $\left(0.1 \mathrm{~mol} \mathrm{~L}^{-1}\right.$ and $\left.\mathrm{pH} 7.3\right)$, dehydrated in ethanol series and metalized in gold. The images were captured with

Table 1. Asteraceae species studied, their respective vouchers and the collecting municipality, in Sand-fields areas, southwest Rio Grande do Sul State, Brazil.

\begin{tabular}{|c|c|c|}
\hline Tribes/ Species & Voucher & Municipality of collection \\
\hline \multicolumn{3}{|l|}{ Tribe Astereae } \\
\hline Noticastrum acuminatum (DC.) Cuatrec. & UNOP 8759 & Alegrete \\
\hline \multicolumn{3}{|l|}{ Tribe Cichorieae } \\
\hline Hieracium commersonii Monnier & UNOP 8761 & São Francisco de Assis \\
\hline \multicolumn{3}{|l|}{ Tribe Eupatorieae } \\
\hline Chromolaena squarrulosa (Hook. \& Arn.) R.M. King \& H. Rob. & UNOP 8763 & Manoel Viana \\
\hline Eupatorium subhastatum Hook. \& Arn. & UNOP 8764 & Manoel Viana \\
\hline Gyptis crassipes (Hieron.) R.M. King \& H.Rob. & UNOP 8861 & Manoel Viana \\
\hline $\begin{array}{l}\text { Gyptis tanacetifolia (Gillies ex Hook. \& Arn.) D.J.N. Hind \& } \\
\text { Flann }\end{array}$ & UNOP 8750 & Manoel Viana \\
\hline Mikania thapsoides DC. & UNOP 8762 & Manoel Viana \\
\hline Praxelis diffusa (Rich.) Pruski & UNOP 8730 & Manoel Viana \\
\hline \multicolumn{3}{|l|}{ Tribe Gnaphalieae } \\
\hline Achyrocline satureioides (Lam.) DC. & UNOP 8720 & São Francisco de Assis \\
\hline
\end{tabular}


Table 1 (continuation)

\begin{tabular}{lcc}
\hline Tribes/ Species & Voucher & Municipality of collection \\
\hline Facelis retusa (Lam.) Sch.Bip. & UNOP 8753 & São Francisco de Assis \\
Gamochaeta americana (Mill.) Wedd. & UNOP 8755 & São Francisco de Assis \\
Gamochaeta falcata (Lam.) Cabrera & UNOP 8751 & São Francisco de Assis \\
Lucilia acutifolia (Poir.) Cass. & UNOP 8721 & Manoel Viana \\
Lucilia nitens Less. & UNOP 8736, & São Francisco de Assis
\end{tabular}

Tribe Heliantheae

Aspilia montevidensis (Spreng.) Kuntze

UNOP 8727, 8728

Dimerostemma grisebachii (Baker) M.D.Moraes

UNOP 8739

Tribe Inuleae

Pterocaulon alopecuroides (Lam.) DC.

UNOP 8745

Pterocaulon angustifolium DC.

UNOP 8722 , 8723

Pterocaulon polystachyum DC.

UNOP 8760

Stenachaenium riedelli Baker

UNOP 8744 , 8743

São Francisco de Assis Manoel Viana Manoel Viana

São Francisco de Assis Manoel Viana

São Francisco de Assis

Tribe Millerieae

Acanthospermum australe (Loefl.) Kuntze

UNOP 8741

Tribe Mutisieae

Chaptalia integerrima (Vell.) Burkart

UNOP 8748

Tribe Neurolaeneae

Calea uniflora Less.

UNOP 8738 , 8737

São Francisco de Assis Manoel Viana

Tribe Senecioneae

Senecio leptolobus DC.

UNOP 8752

Senecio oxyphyllus DC.

UNOP 8754

Senecio selloi (Spreng.) DC.

UNOP 8746

Tribe Vernonieae

Centratherum camporum (Hassl.) Malme

Chrysolaena cognata (Less.) Dematt.

Chrysolaena flexuosa (Sims) H.Rob.

UNOP 8758

UNOP 8757 , 8756

São Francisco de Assis

UNOP 8860, 8859

São Francisco de Assis São Francisco de Assis Alegrete

\section{Alegrete}

São Francisco de Assis

Lessingianthus brevifolius (Less.) H.Rob.

UNOP 8726 , 8725,8724

Lessingianthus macrocephalus (Less.) H.Rob.

UNOP 8734

Orthopappus angustifolius (Sw.) Gleason

UNOP 8742

Vernonanthura chamaedrys (Less.) H.Rob.

UNOP 8858

Vernonanthura nudiflora (Less.) H.Rob.

UNOP 8733 , 8732,8731

São Francisco de Assis

São Francisco de Assis

São Francisco de Assis Manoel Viana

São Francisco de Assis

Alegrete 
the aid of an EVO LS-10 scanning electron microscope and SmartSEM software. This analysis was performed at the Laboratory of Scanning Electron Microscopy of the Science and Technology Park - Tecnovates of the Universidade do Vale do Taquari - Univates, Lajeado, RS.

For the anatomical analyses in light microscopy (LM), three fertile individuals of each species were collected, and fully expanded leaf blades were fixed in FAA 50 (37\% formaldehyde, glacial acetic acid and $50 \%$ alcohol in a ratio of 1:1:18) (Johansen 1940) and preserved in $70 \%$ alcohol. For leaf blade observation in frontal view $(\mathrm{FV})$, fragments of the leaf medial region were dissociated with hydrogen peroxide and acetic acid at a concentration of 1:1 (Franklin 1945, modified) and then stained with basic fuchsin in $50 \%$ alcohol. The trichomes were also analyzed in transverse view of the leaf blade, and cross-sections (CS) were performed by hand, with the aid of a razor blade, in the median region of the leaf blades of the species under study. Cross-sections were clarified with $50 \%$ sodium hypochlorite, stained with alcian blue and basic fuchsin (Kraus et al. 1998) and then mounted on semi-permanent, glycerinated gelatin (Kaiser 1880).

All FV and CS images were captured using a DP041 digital camera coupled to an Olympus Bx70 photomicroscope, using the DP Controller program, at the Photomicroscopy Laboratory of the Center for Biological Sciences and Health of the Universidade Estadual do Oeste do Paraná - Unioeste, Cascavel, PR.

The trichomes were identified and characterized based on the system proposed by Ramayya (1962) and complementary literature (Castro et al. 1997, Martins 2003, Budel et al. 2006, Duarte et al. 2011, Trindade et al. 2014, Wagner et al. 2014).

\section{Results and Discussion}

Based on the proposal of Ramayya (1962) and complementary literature, 11 types of trichomes were identified and characterized, of which three were glandular and eight non-glandular. Most of the analyzed species present both glandular and nonglandular trichomes on the same leaf blade, except for Senecio leptolobus DC. and Senecio selloi (Spreng.) DC., which presented only glandular trichomes and Vernonanthura chamaedrys (Less.) H.Rob. that had only non-glandular trichomes (table 2). As for distribution, the trichomes (glandular and nonglandular) occur generally on both surfaces of the leaf blade and, when restricted to one side, this is predominantly the abaxial (table 2 ).
The variety of trichome types observed in the species of this study corroborates with other studies already done in the family that highlight the diversity of trichomes in Asteraceae (Solereder 1908, Ramayya 1962, Castro et al. 1997, Amrehn et al. 2013). Faced with this morphological diversity, studies on trichomes in the family have resulted in a variety of terminologies that often overlap in meanings and make it difficult to compare the types of trichomes found in the various family representatives (Wagner et al. 2014). Another factor that hinders these comparisons is the use of the same terminology for different types of trichomes (Wagner et al. 2014). In this way, the identification and characterization of trichomes in the family is not an easy task. The types of trichomes identified in this study are characterized and discussed below.

Glandular trichomes - In most species they occur on both surfaces of the leaf blade (table 2, figures 1-2), generally in depressions in the epidermis (figures $1 \mathrm{~g}-\mathrm{h}$, $2 \mathrm{~b}-1)$, corroborating with other studies that reveal glandular trichomes of Asteraceae in this position (Solereder 1908, Metcalfe \& Chalk 1950, Trindade 2013).

Three types of glandular trichomes were identified and characterized in the species studied here: recurved on the epidermis, erect-capitate and uniseriate to multiseriate vesicular-capitate.

Recurved on the epidermis (G1) - multicellular, uniseriate, filamentous, recurved on the epidermis; foot and stalk with 3-4 cells; head unicellular, varying from globoid to spatulated (figure 1a-c). They have been observed on both leaf surfaces of the species of tribe Eupatorieae (figure 1a-c), except for Mikania thapsoides DC., in Aspilia montevidensis (Spreng.) Kuntze and Dimerostemma grisebachii (Baker) M.D.Moraes (Heliantheae tribe) (table 2). Studies with other representatives of the Eupatorieae (Amorin et al. 2014, Trindade et al. 2014, Fernandes et al. 2016) and Heliantheae tribes (Empinotti 2005, Oliveira et al. 2013) also indicate the occurrence of this type of trichome, which can be interpreted as a probable affinity between these tribes (Castro et al. 1997, Fernandes et al. 2016).

Erect-capitate (G2) - multicellular, uniseriate or biseriate, filamentous, erect and capitate (figure 1d-1). The number of foot and stalk cells, as well as the morphology (semigloboid, globoid, oblong-ovate or ovate) and the number of head cells (unicellular, bicellular or multicellular) may vary. The foot and stalk are uniseriate with 2-4 cells in Calea uniflora 


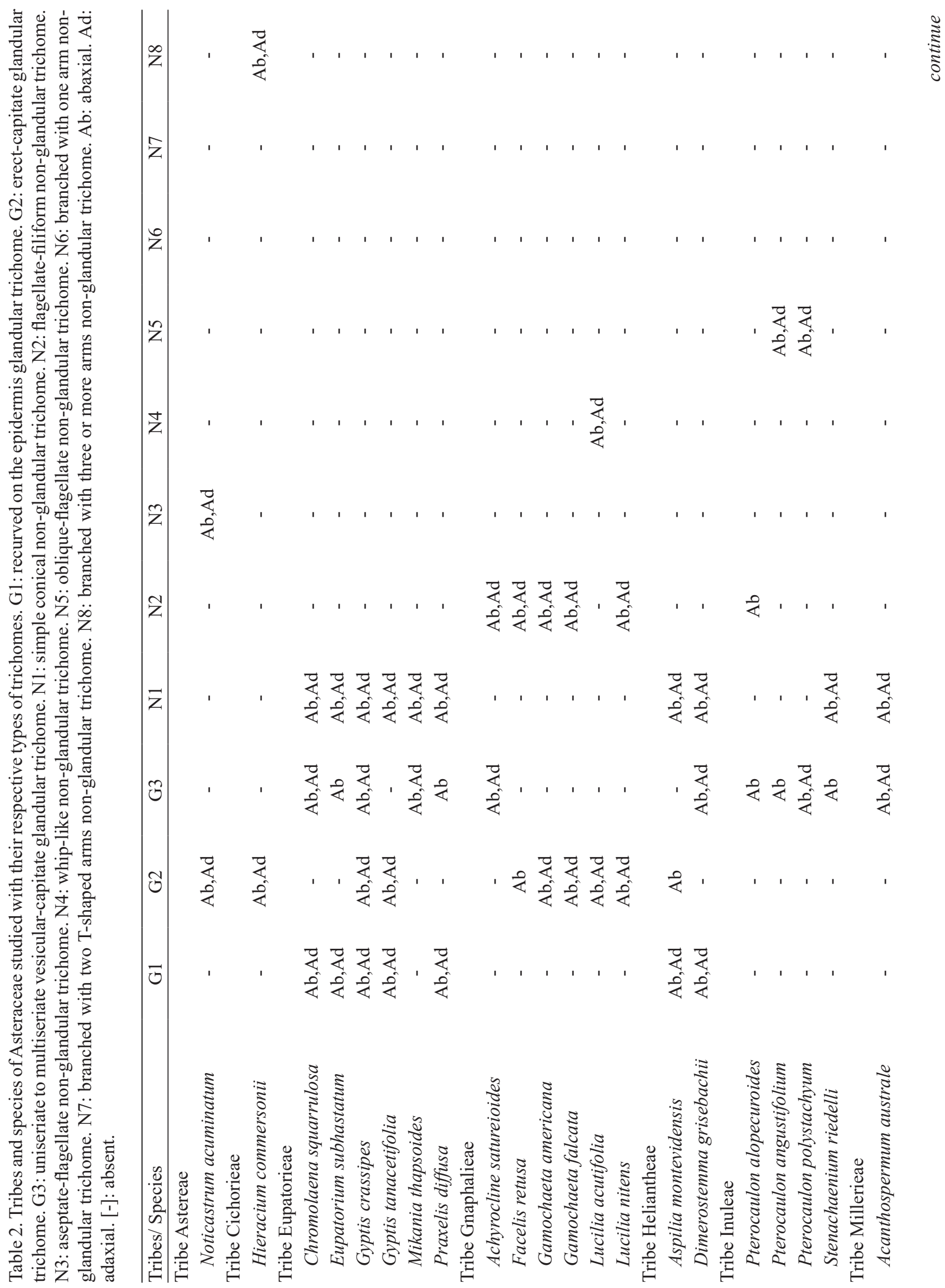




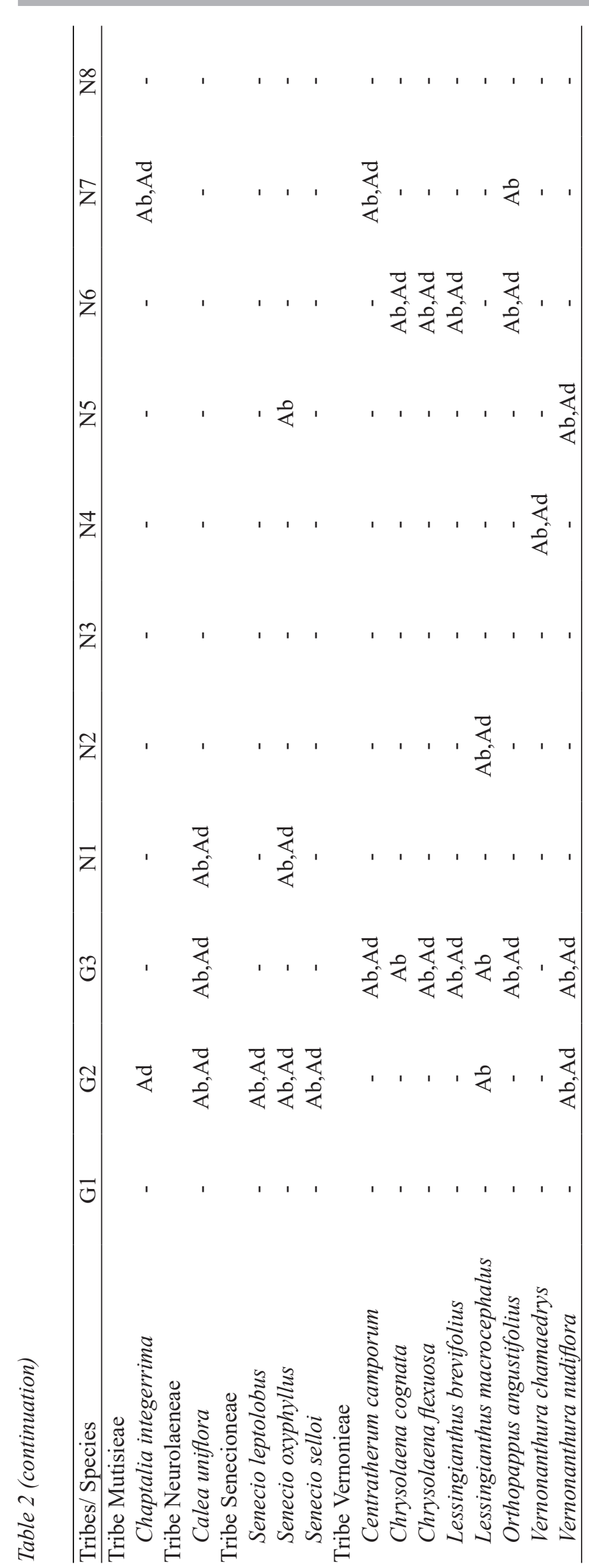

Less. (figure 1h), Lessingianthus macrocephalus (Less.) H.Rob. (figure 1d) and Vernonanthura nudiflora (Less.) H.Rob. (figure 1e); are uniseriate to biseriate with 3-11 cells or pairs of cells in the studied members of the tribes Astereae, Heliantheae (except Dimerostemma grisebachii) (figure 1f), Mutisieae, Senecioneae (figure 1k-1), Gnaphalieae (except Achyrocline satureioides (Lam.) DC.) and in Gyptis tanacetifolia (Gillies ex Hook. \& Arn.) D.J.N. Hind \& Flann and Gyptis crassipes (Hieron.) R.M. King \& H.Rob. (figure 1j); are biseriate with 6-8 pairs of cells in Hieracium commersonii Monnier (tribe Cichorieae). The head is unicellular with an oblong-ovate or ovate shape in Lessingianthus macrocephalus (figure 1d) and Vernonanthura nudiflora (figure 1e); unicellular or bicellular (in biseriate trichomes) and of a semigloboid shape (figure 1f-g) in Aspilia montevidensis (figure 1f), Gyptis tanacetifolia, Noticastrum acuminatum (DC.) Cuatrec. and all species of the Gnaphalieae tribe (except Achyrocline satureioides); unicellular to multicellular, uniseriate to multiseriate, of globoid shape, in Calea uniflora (figure 1h), Chaptalia integerrima (Vell.) Burkart (figure 1i), Gyptis tanacetifolia, Gyptis crassipes (figure 1j), Hieracium commersonii and all species of the Senecioneae tribe studied (figure 1k-1).

These trichomes occur on both sides of the leaf blade in most species and only on one side in some species (table 2). In Senecio leptolobus these trichomes are restricted to the region of midrib depression and in Calea uniflora they occur together with uniseriate to multiseriate vesicular-capitate glandular trichomes - G3 (figure 1h).

Erect-capitate glandular trichomes were quite representative in this study, occurring in $50 \%$ of the analyzed species. Trichomes with an oblong-ovate head similar to those observed in Lessingianthus macrocephalus were also described in Lessingianthus buddleiifolius (Mart. ex DC.) H. Rob. (Santos 2013), although these are indicated as structures unpublished by the author. Thus, information about these trichomes is increased for the genus Lessingianthus. Similar trichomes to the semigloboid head were reported by Castro et al. (1997), Martins (2003) and Duarte et al. (2011) in other species of Asteraceae. Globoid head trichomes were also reported in other representatives of the Senecioneae tribe (Martins 2003, Rojas-Leal et al. 2017) and trichome heads with this shape have already been described in Calea uniflora by 


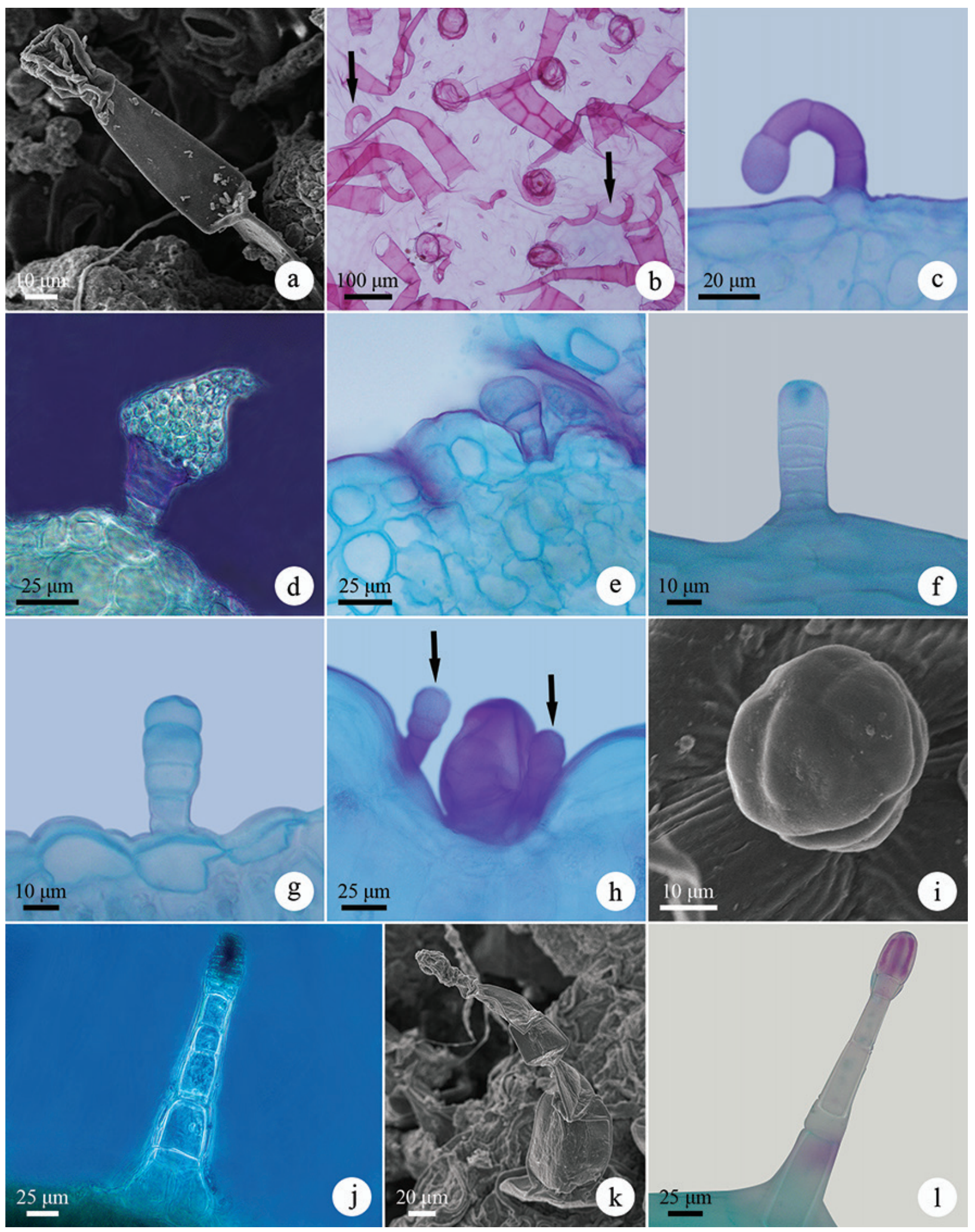

Figure 1. Glandular trichomes of Asteraceae species in light microscopy (b-h, j, l) and scanning electron microscopy (a, i, k). a-c. Recurved on the epidermis glandular trichomes (G1) in Chromolaena squarrulosa (Hook. \& Arn) R.M. King \& H. Rob., Gyptis crassipes and Eupatorium subhastatum, respectively. d-e. Erect-capitate glandular trichome (G2) with oblong-ovate head in Lessingianthus macrocephalus and Vernonanthura nudiflora, respectively. f-g. Erect-capitate glandular trichome (G2) with semigloboid head in Aspilia montevidensis and Lucilia acutifolia, respectively. h-j. Erect-capitate glandular trichome (G2) with globoid head in Calea uniflora, Chaptalia integerrima and Gyptis crassipes, respectively. k-1. Erect-capitate glandular trichome (G2) with globoid head in Senecio selloi. 
Budel et al. (2006). In this way, knowledge about the occurrence and morphological variation of this representative type of trichome in the Asteraceae species is increased.

Uniseriate to multiseriate vesicular-capitate (G3) multicellular, uniseriate, biseriate or multiseriate, capitate and vesicular (figure 2a-1). The foot and stalk vary from 3-8 cells, usually in a single series (figure $2 \mathrm{~b}-\mathrm{d}$ ) or two series (figure $2 \mathrm{e}-\mathrm{g}$ ), being multiseriate only in Mikania thapsoides (figure 2h). The head presents 1-2 cells or pairs of cells (biseriate) (figure $2 \mathrm{i}-1)$ or up to three cells (multiseriate) (figure $2 \mathrm{~h}$ ). The vesicle is persistent or may collapse early (figure $2 \mathrm{e}, 1)$. They are generally found in depressions of the epidermis (figure $2 b, i-j$ ) on the abaxial surface of seven species of distinct tribes (Eupatorium subhastatum Hook. \& Arn., Praxelis diffusa (Rich.) Pruski, Pterocaulon alopecuroides (Lam.) DC., Pterocaulon angustifolium DC., Stenachaenium riedelli Baker, Chrysolaena cognata (Less.) Dematt. and Lessingianthus macrocephalus) or on both sides of the leaf blade of the 13 remaining species in which they occur (table 2). In Lessingianthus brevifolius (Less.) H.Rob. these trichomes occur restricted to regions of the midrib depression.

Among the glandular trichomes, this type of trichome was the most representative, occurring in 20 of the 34 species studied (58\% of species). The occurrence of these trichomes in the uniseriate, biseriate or multiseriate format was indicated by Metcalfe \& Chalk (1950) and other authors have also reported the occurrence of this type of trichome, mainly in the biseriate format, as common in the family Asteraceae (Solereder 1908, Castro et al. 1997, Bombo et al. 2012, Trindade 2013, Fernandes 2014), being this format also the most commonly found among the species studied here.

In the species studied here, these trichomes were observed in members of different tribes (Eupatorieae, Vernonieae, Inuleae, Neurolaeneae, Millerieae, Gnaphalieae and Heliantheae), as well as reported in other studies involving species of different tribes of the family: Eupatorieae (Castro et al. 1997, Monteiro et al. 2001, Del-Vecho-Vieira et al. 2008, Trindade 2013, Trindade et al. 2014, Fernandes et al. 2016), Heliantheae (Empinotti 2005, Martins et al. 2006, Bombo et al. 2012, Amrehn et al. 2013, Oliveira et al. 2013), Vernonieae (Narayana 1979, Castro et al. 1997, Empinotti 2005, Empinotti \& Duarte 2008, Appezzato-da-Glória et al. 2012, Santos 2013, Sosa et al. 2014), Neurolaeneae (Castro et al. 1997, Budel et al. 2006), Millerieae (Araújo et al. 2013), Mutisieae (Castro et al. 1997, Freire et al. 2002, Melo-de-Pinna 2004), Astereae (Cortadi et al. 1999, Budel \& Duarte 2007) and Inuleae (Castro et al. 1997). Although the literature (cited above) indicates the occurrence of uniseriate to multiseriate vesicular-capitate trichomes in representatives of the tribes Mutisieae and Astereae, these were not observed among the species of these tribes studied here, possibly due to the analysis of only one species of each of these tribes.

In addition to their wide distribution and morphological diversity in the family, glandular trichomes are responsible for the secretion of different compounds of secondary metabolism (mucilage, resinous substances, tannins, essential oils, among others), which perform important biological and pharmacological activities conferring on the family great economic importance in the production of bioactive compounds (Metcalfe \& Chalk 1950, Trindade 2013, Fernandes 2014).

Non-glandular trichomes - Most species present only one type of non-glandular trichome, except Senecio oxyphyllus DC. and Orthopappus angustifolius (Sw.) Gleason, both with two types (table 2). In most species, they occur on both sides of the leaf blade (table 2) and are generally densely distributed on the leaf surface.

Eight types of non-glandular trichomes were identified and characterized: simple conical; flagellatefiliform; aseptate-flagellate; whip-like; obliqueflagellate; branched with one arm; branched with two T-shaped arms; branched with three or more arms (figures 3-4). Due to the morphological similarity of the head (long, flagellate and acute apex) of the non-glandular trichomes of the flagellate-filiform, aseptate-flagellate, whip-like and oblique-flagellate type, in the literature (Ramayya 1962, Narayana 1979, Mussury et al. 2007, Sancho et al. 2010, RedondaMartínez et al. 2012, 2016), the same terminology can be used in the identification and characterization of different trichomes thus hindering comparison with the trichomes described in this study.

Simple conical (N1) - uniseriate; simple or compound foot and entire body (undifferentiated) consisting of 2-5 (figure 3a-e) or up to eight cells as in Stenachaenium riedelli (figure $3 \mathrm{f}$ ); basal cells broader than long and the apical cell with a conical or pointed shape (figure 3a-e). The lateral walls are usually thick and may have adornments as in Aspilia montevidensis and Dimerostemma grisebachii (figure 3c). These 


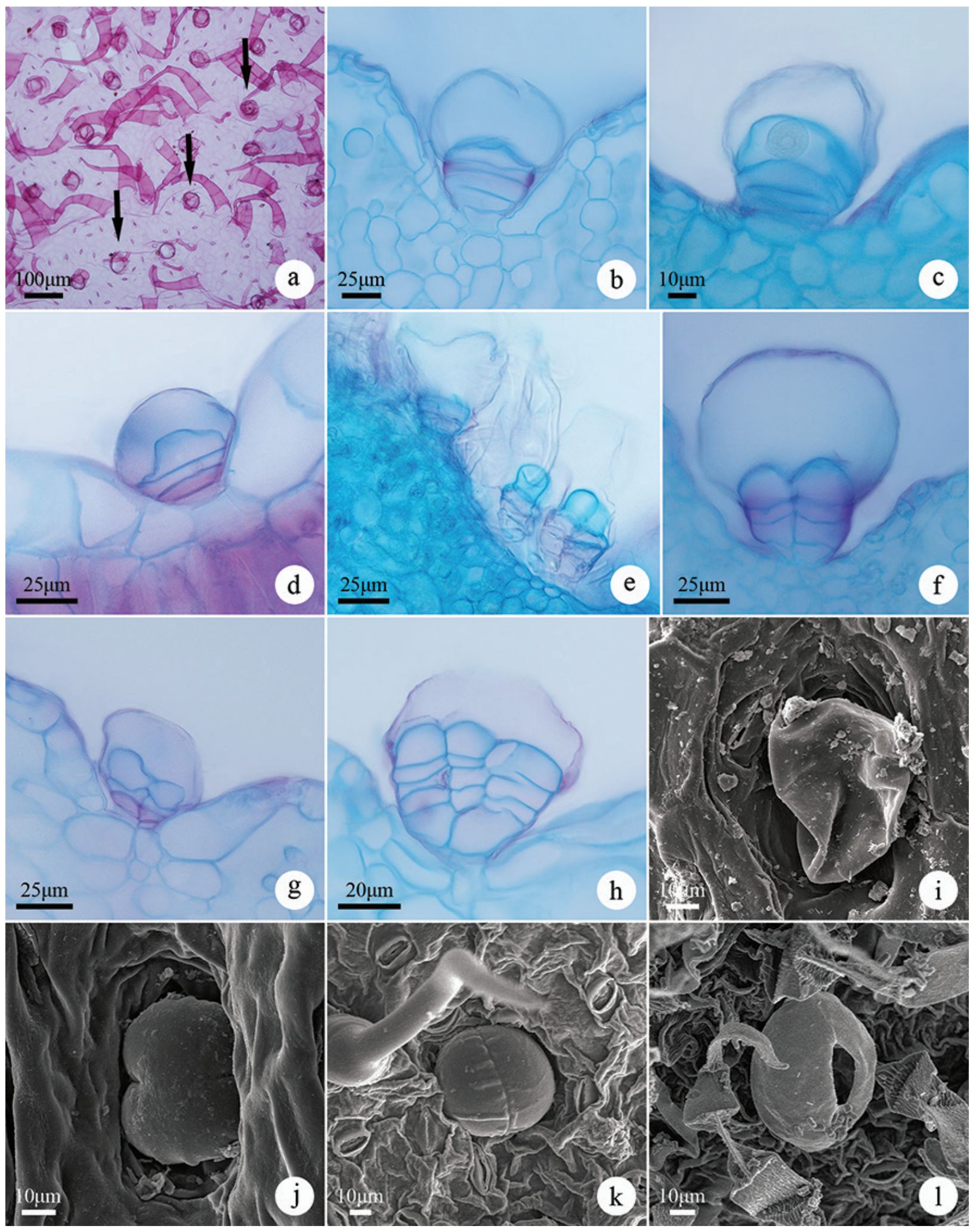

Figure 2. Uniseriate to multiseriate vesicular-capitate glandular trichomes (G3) of the species of Asteraceae in light microscopy (a-h) and scanning electron microscopy (i-1). a. Frontal view of the trichomes of Gyptis crassipes. b-d. Uniseriate vesicular-capitate glandular trichomes of Gyptis crassipes, Vernonanthura nudiflora and Orthopappus angustifolius, respectively. e-g. Biseriate vesicular-capitate glandular trichomes of Pterocaulon angustifolium, Eupatorium subhastatum and Orthopappus angustifolius, respectively. h. Multiseriate vesicular-capitate glandular trichomes of Mikania thapsoides. i-1. Uniseriate to multiseriate vesicular-capitate glandular trichomes of Lessingianthus brevifolius, Vernonanthura nudiflora, Chrysolaena cognata and Mikania thapsoides, respectively. 


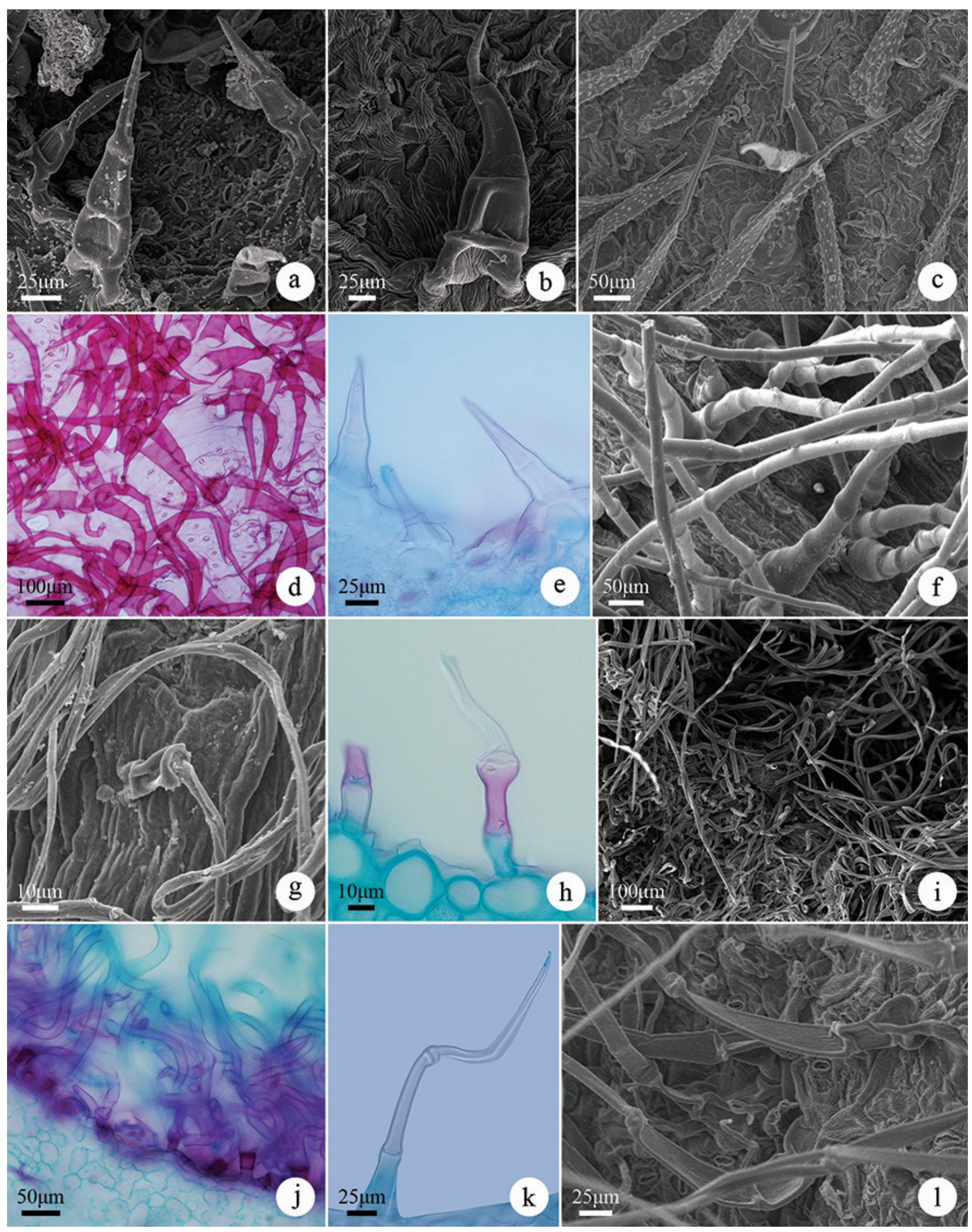

Figure 3. Non-glandular trichomes of the species of Asteraceae in light microscopy (d, e, h, j, k) and scanning electron microscopy (a-c, f, g, i, l). a-c. Simple conical trichomes (N1) in Eupatorium subhastatum, Calea uniflora and Dimerostemma grisebachi, respectively. d. Frontal view of the simple conical trichomes (N1) of Gyptis crassipes. e-f. Simple conical trichomes (N1) of Eupatorium subhastatum and Stenachaenium riedelli, respectively. g-h. Flagellate-filiform trichomes (N2) of Facelis retusa (Lam.) Sch.Bip. i-j. Flagellate-filiform trichomes (N2) of Lessingianthus macrocephalus. k-1. Aseptate-flagellate trichome (N3) of Noticastrum acuminatum. 
trichomes occur on both sides of the leaf blade of all species of the tribe Eupatorieae, Heliantheae, Millerieae, Neurolaeneae and in Stenachaenium riedelli (Inuleae) and Senecio oxyphyllus (Senecioneae) (table 2).

This type was the most representative among the non-glandular trichomes, occurring in 12 of the 34 species studied (35\% of species). Trichomes of this type are considered common in the family (Smiljanic 2005) and described for members of distinct tribes, such as Tithonia diversifolia (Hemsl.) A.Gray (Heliantheae tribe) (Empinotti 2005), Mikania lanuginosa DC. (Amorin et al. 2014) and Trichogonia cinerea (Fernandes et al. 2016) in the tribe Eupatorieae, in some species of the subtribe Leiboldiinae (tribe Vernonieae) (Redonda-Martínez et al. 2016) and in species of Podocoma (tribe Astereae) (Sancho et al. 2010). In these studies, the authors reveal the occurrence of variations in the number of cells of the simple conical trichomes,

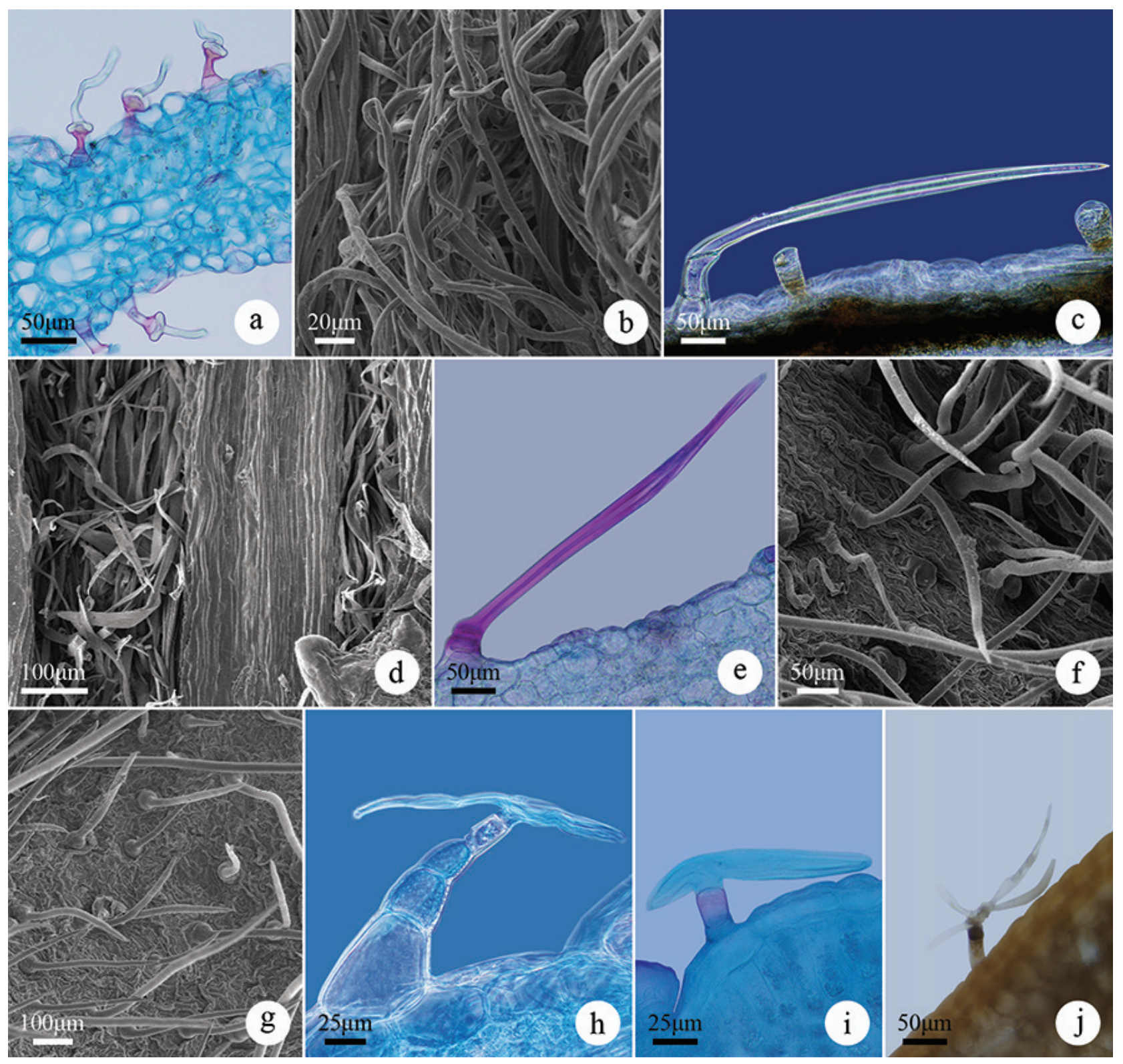

Figure 4. Non-glandular trichomes of the species of Asteraceae in light microscopy (a, c, e, h, i, j) and scanning electron microscopy (b, d, f, g). a-b. Whip-like trichome (N4) of Lucilia acutifolia. c-d. Oblique-flagellate trichome (N5) of Pterocaulon polystachyum and Vernonanthura nudiflora, respectively. e-f. Branched witch one arm trichome (N6) of Orthopappus angustifolius. g. Branched witch one arm trichome (N6) of Chrysolaena cognata. h-i. Branched witch two T-shaped arms trichome (N7) of Centratherum camporum. j. Branched witch three or more arms trichome (N8) in Hieracium commersonii. 
corroborating with this study which found the largest number of cells in Stenachaenium riedelli in relation to the other species with simple conical trichomes. In addition, the description of these trichomes in Acanthospermum australe (Loefl.) Kuntze and Calea uniflora corroborates with the identification and characterization of the simple conical trichomes observed by Araújo et al. (2013) and Martins et al. (2006) in Acanthospermum australe and Budel et al. (2006) in Calea uniflora.

Flagellate-filiform (N2) - uniseriate, filiform; simple or compound foot and body differentiated into stalk and head; stalk with 2-4 cells generally isodiametric or with 1-2 basal cells broader than long (figure 3g-h); unicellular, flagellate and long head, tapering to a pointed apex (figure 3i-j). These trichomes occur on both surfaces of Lessingianthus macrocephalus and all species of the Gnaphalieae tribe (except in Lucilia acutifolia (Poir.) Cass.) and only on the abaxial side of Pterocaulon alopecuroides (table 2). As for the abaxial surface of most species, the trichomes cover the entire leaf surface of this side.

Trichomes like the flagellate-filiform observed in this study were also found in other species of the Gnaphalieae (Smiljanic 2005, Mussury et al. 2007) and Vernonieae (Narayana 1979, Santos 2013, Redonda-Martínez et al. 2016) tribes, although in these studies the authors used the term "whip" for characterization of the apical cell, whereas in our study this term describes another type of non-glandular trichome.

Aseptate-flagellate (N3) - uniseriate, flagellate; simple or compound foot and body differentiated into stalk and head; stalk consisting of 2-3 cells, one or two basal cells being broader than long and the other(s) being longer than broad; head unicellular, clearly delimited from the stalk, long and tapering upward with a pointed apex (figure $3 \mathrm{k}-1$ ). They occur on both sides of the leaf blade only in Noticastrum acuminatum (table 2). Similar trichomes were observed in the leaf margin of Calendula officinalis L. (Calenduleae) (Ramayya 1962) and on the stem and leaves of Gnaphalium polycaulon Pers. (Gnaphalieae) (Jana 2014).

Whip-like (N4) - uniseriate, flagellate; simple or compound foot and body differentiated into stalk and head; stalk with two cells forming a enlarged base upwards (figure 4a); the head is composed of a generally long, whip-shaped flagellate cell whose base is broad and tapering upward to a pointed apex (figure 4a-b). These trichomes occur on both leaf surfaces of Lucilia acutifolia and Vernonanthura chamaedrys (table 2). In the first, they cover the whole leaf surface of both sides and in the second only on the abaxial surface, whereas on the adaxial surface the trichomes are sparsely distributed.

This type of trichome was described for the genus Lucilia by Metcalfe \& Chalk (1950) and was also characterized as a peculiar trichome in Lucilia nitens Less. (Duarte et al. 2011), although in our study this species did not present this trichome, but rather the flagellate-filiform trichome (N2).

Oblique-flagellate (N5) - uniseriate, flagellate; simple or compound foot and body differentiated into stalk and head; stalk consisting of 2-5 cells with at least one basal cell broader than long; unicellular or multicellular head with a cell(s) longer than broad, flagellate, continuous with the stalk or clearly delimited from it by an oblique septum (figure $4 c-d)$. They occur on both sides of the leaf blade of Pterocaulon angustifolium, Pterocaulon polystachyum DC., Vernonanthura nudiflora and only on the abaxial surface of Senecio oxyphyllus (table 2). In Pterocaulon angustifolium they cover the entire surface of the abaxial surface and are more sparsely distributed on the adaxial surface.

Trichomes like the oblique-flagellate type were observed by Cabrera \& Ragonese (1978) in American species of the genus Pterocaulon (including Pterocaulon angustifolium and Pterocaulon alopecuroides, however, in our study this last species did not present this type of thichome), but these authors use the term "non-septate flagelliform" to identify this trichome. Freire et al. (2002) also indicated the occurrence of these trichomes in some species of the genus Gochnatia (Gochnatieae).

Branched witch one arm (N6) - uniseriate; simple or compound foot and body differentiated into stalk and head; stalk consisting of 1-3 cells, one or two of the basal cells being broader than long; unicellular head with a flat arm channeled into the base, forming an angle with the stalk, pointed apex (figure $4 \mathrm{e}-\mathrm{g}$ ) and thick lateral walls. They occur on both surfaces of the leaf blade of some representatives of the Vernonieae tribe (Chrysolaena cognata, Chrysolaena flexuosa (Sims) H.Rob., Lessingianthus brevifolius and Orthopappus angustifolius) (table 2). Similar trichomes were described for Elepanthopus mollis Kunth (Empinotti 2005, Empinotti \& Duarte 2008) 
and for some species of the genus Vernonia (Narayana 1979).

Branched witch two T-shaped arms (N7) - uniseriate; simple or compound foot and body differentiated into stalk and head; stalk with 1-5 or more cells with at least one of the basal cells broader than long and the other cells generally cylindrical; unicellular head with two arms generally flat, channeled in the base and which may vary in shape (figure $4 \mathrm{~h}-\mathrm{i}$ ). In the case of Orthopappus angustifolius (abaxial surface) and Centratherum camporum (Hassl.) Malme (both sides) (figure 4h-i) the two arms are short, having unequal sizes and forming a T-shaped structure together with the stalk (table 2). In Chaptalia integerrima (both surfaces) the arms are long and spread laterally as in the T-shaped, but tend to curl (table 2). The apex of the arms is pointed or rounded. These trichomes cover the entire leaf surface of the abaxial surface of Chaptalia integerrima.

Trichomes of this type are frequent in the species of the Vernonieae tribe and can be used in the taxonomy of the representatives of this tribe (Narayana 1979, Redonda-Martínez et al. 2012, Wagner et al. 2014). Similar trichomes were also observed in some species of the genus Gochnatia (Gochnatieae) (Freire et al. 2002).

Branched witch three or more arms (N8) - uniseriate; simple or compound foot and body differentiated into stalk and head; stalk composed of 1-2 cells longer than broad; branched unicellular head with 3-5 long and thin arms that spread apart at different angles (figure 4j). They occur only in Hieracium commersonii, on both sides of the leaf blade (table 2). Similar trichomes have been described in some species of the genus Gochnatia (Gochnatieae) (Freire et al. 2002) and the subtribe Lychnophorinae (Vernonieae tribe), where they are considered frequent (Wagner et al. 2014).

Due to their direct contact with the environment, glandular and non-glandular trichomes can influence many physiological and ecological aspects of plants, protecting them against stressful biotic and abiotic factors (Johnson 1975, Werker 2000, Krak \& Mráz 2008, Trindade et al. 2014). Glandular trichomes are responsible for the secretion of different substances of secondary metabolism, which can form a continuous layer on the surface of the plant and thus act in reflecting light and in decreasing the temperature of the leaf (Wagner 1991, Perveen et al. 2016).
In addition, the secreted substances can act in the chemical defense against pathogens and herbivores (Wagner 1991, Trindade et al. 2014).

Non-glandular trichomes play an important role in protecting the leaves against pathogens, herbivores, high temperatures, excessive light and excessive water loss (Johnson 1975, Werker 2000, Wagner et al. 2004, Trindade et al. 2014). The functions developed by them depend on their morphology, orientation, and density (Werker 2000, Wagner et al. 2004). Longer, non-glandular trichomes which cover the entire leaf surface, as observed in most of the species studied, may act as a mechanical barrier against pest attack (Levin 1973), decrease water loss through reflection (Ehleringer 1984, Wagner et al. 2014) and influence the wettability of the leaves making them repellent to water and thus preventing the growth of pathogenic microorganisms, the deposition of pollutants and favoring photosynthetic yield (Wang et al. 2015, Rojas-Leal et al. 2017).

Considering that the species of this study occur in Sand-fields, which are characterized by high temperatures, high light intensity, water scarcity, sandy soils and strong winds, the high frequency of glandular and non-glandular trichomes in these species can constitute an adaptive strategy to these adverse environmental conditions (Costa et al. 2011). From a taxonomic point of view, the morphological diversity and the distribution of trichomes in the Asteraceae family can contribute to systematics studies at different taxonomic levels of the family, since they have been shown not to be influenced by environmental and climatic factors, thus constituting reliable taxonomic characters (Narayana 1979, Wagner et al. 2014).

In our study, the morphological diversity of trichomes seems to be useful in the taxonomy of the family at the tribal level. Considering the tribes with the largest number of species sampled, we verified that the recurved on the epidermis glandular trichomes (G1) are more frequent in the Eupatorieae tribe ( $83 \%$ of the species studied) whereas erect-capitate glandular trichomes (G2) are more frequent in the Gnaphalieae (83\%) and Senecioneae (all species) tribes. Uniseriate to multiseriate vesicular-capitate glandular trichomes (G3) are more frequent in the Vernonieae (87\%), Eupatorieae (83\%) and Inuleae (all species) tribes. Among the non-glandular trichomes, the simple conical type (N1) is more frequent in the Eupatorieae tribe, while the flagellate-filiform (N2) and the branched witch one arm type (N6) are the most 
frequent in the Gnaphalieae tribe $(83 \%)$ and among members of the Vernonieae tribe (50\%), respectively. Trichomes of the aseptate-flagellate (N3) and branched witch three or more arms (N8) type are restricted to the Astereae and Cichorieae tribes, respectively, although in each of these tribes only one species has been sampled.

These taxonomic inferences are closely related to the number of species sampled in each of the tribes studied, and the tribes with the highest frequency of some type of trichome are also the ones with the highest species richness and the highest sampling rate in our study: Vernonieae (23\%), Eupatorieae and Gnaphalieae (18\%). Thus, the value of trichomes as a taxonomic character at the tribal level in this study can be greatly increased by sampling more species in each tribe, especially those in which only one or two species were sampled (Astereae, Cichorieae, Heliantheae, Millerieae, Mutisieae, Neurolaeneae) and also with the joint analysis of other characters relevant to taxonomy. In addition, studies that develop a more detailed terminological analysis and, if possible, the standardization of the nomenclature used in the identification and characterization of trichomes in Asteraceae would facilitate their use in taxonomic studies of the family.

\section{Acknowledgments}

We acknowledge the team of the Scanning Electron Microscopy Laboratory of Univates - RS for providing equipment and technical support for scanning electron microscopy analysis, and Gustavo Heiden, Mara Angelina Galvão Magenta, Eduardo Pasini and Roberto Lourenço Esteves for their assistance in identification of species. We also thank the Coordenação de Aperfeiçoamento de Pessoal de Nível Superior - CAPES for the scholarship of the first author and the Araucária Foundation (51223/2017) for financial assistance of this research.

\section{Literature cited}

Adedeji, O. \& Jewoola, O.A. 2008. Importance of leaf epidermal characters in the Asteraceae family. Notulae Botanicae Horti Agrobotanici Cluj-Napoca 36: 7-16.

Aleykutty, K.M. \& Inamdar, J.A. 1980. Structure, ontogeny and classification of trichomes in Ranales. Feddes Repertorium 91: 95-108.

Almeida, A.M., Fonseca, C.R., Prado, P.I., AlmeidaNeto, M., Diniz, S., Kubota, U., Braun, M.R., Raimundo, R.L.G., Anjos, L.A., Mendonça, T.G., Futada, S.M. \& Lewinsohn, T.M. 2005. Diversidade e ocorrência de Asteraceae em cerrados de São Paulo. Biota Neotropica 5: 1-17.
Amorin, M., Paula, J.P., Silva, R.Z., Farago, P.V. \& Budel, J.M. 2014. Pharmacobotanical study of the leaf and stem of Mikania lanuginosa for its quality control. Revista Brasileira de Farmacognosia 24: 531-537.

Amrehn, E., Heller, A. \& Spring, O. 2013. Capitate glandular trichomes of Helianthus annuus (Asteraceae): ultrastructure and cytological development. Protoplasma 251: 161-167.

Anderberg, A.A., Baldwin, B.G., Bayer, R.G., Breitwieser, J., Jeffrey, C., Dillon, M.O., Eldenas, P., Funk, V., Garcia-Jacas, N., Hind, D.J.N., Karis, P.O., Lack, H.W., Nesom, G., Nordenstam, B., Oberprieler, C.H., Panero, J.L., Puttock, C., Robinson, H., Stuessy, T.F., Susanna, A., Urtubey, E., Vogt, R., Ward, J. \& Watson, L.E. 2007. Compositae. In: J.W. Kadereit \& C. Jeffrey (eds.). The families and genera of vascular plants: flowering plants Eudicots Asterales. Springer, Berlin, v. 7, pp. 61-588.

Appezzato-da-Glória, B., Costa, F.B., Silva, V.C., GobboNeto, L., Rehder, V.L.G. \& Hayashi, A.H. 2012. Glandular trichomes on aerial and underground organs in Chrysolaena species (Vernonieae - Asteraceae): Structure, ultrastructure and chemical composition. Flora 207: 878-887.

Araújo, E.L., Xavier, H.S., Ferreira, C.P., Randau, K.P. \& Pimentel, R.M.M. 2013. Macro and microscopical identification of two Acanthospermum medicinal plants. Journal of Medicinal Plants Research 7: 2606-2615.

Arunprakash, S., Subramanian, G., Stephen, J., Jayanthi, V., Sasikala, J., Sowmiya, R. \& Indhu, M. 2014. Studies of trichome in five species of Asteraceae. International Journal of Advances in Interdisciplinary Research 1: 1-4.

Azevedo, A.C. \& Kaminski, J. 1995. Considerações sobre os solos dos campos de areia no Rio Grande do Sul. Ciência \& Ambiente 11: 65-70.

Barroso, G.M., Peixoto A.L., Ichaso, C.L.F., Costa, C.G., Guimarães, E.F. \& Lima, H.C. 1991. Sistemática de Angiospermas do Brasil. Editora UFV, Viçosa.

Beretta, M.E., Fernandes, A.C., Schneider, A.A. \& Ritter, M.R. 2008. A família Asteraceae no Parque Estadual de Itapuã, Viamão, Rio Grande do Sul, Brasil. Revista Brasileira de Biociências 6: 189-216.

Berlato, M.A., Farenzena, H. \& Leivas, J. 2006. Probabilidade de precipitação pluvial decendial ser igual ou superior à evapotranspiração de referência na metade sul do Estado do Rio Grande do Sul. Pesquisa Agropecuária Gaúcha 12: 7-16.

Boldrini, I.I. 2009. A flora dos Campos do Rio Grande do Sul. In: V.P. Pillar, S.C. Müller, Z.M.S. Castilhos \& A.V.A. Jacques (eds.). Campos Sulinos: conservação e uso sustentável da biodiversidade. Ministério do Meio Ambiente, Brasília, pp. 63-77. 
Boldrini, I.I., Ferreira, P.M.A., Andrade, B.O., Schneider, A.A., Setubal, R.B., Trevisan, R. \& Freitas, E.M. 2010. Bioma Pampa: diversidade florística e fitofisionômica. Editora Pallotti, Porto Alegre.

Bombo, A.B., Oliveira, T.S., Oliveira, A.S.S., Rehder, V.L.G., Magenta, M.A.G. \& Appezzato-da-Glória, B. 2012. Anatomy and essential oils from aerial organs in three species of Aldama (Asteraceae-Heliantheae) that have a difficult delimitation. Australian Journal of Botany 60: 632-642.

Borges, R.A.X., Saavedra, M.M., Nakajima, J.N. \& Forzza, R.C. 2010. The Asteraceae flora of the Serra do Ibitipoca: analyses of its diversity and distribution compared with selected areas in Brazilian mountain ranges. Systematics and Biodiversity 8: 471-479.

Budel, J.M. \& Duarte, M.R. 2007. Caracteres morfoanatômicos de partes vegetativas aéreas de Baccharis coridifolia DC. (Asteraceae-Astereae). Latin American Journal of Pharmacy 26: 723-731.

Budel, J.M., Duarte, M.R., Farago, P.V. \& Takeda, I.J.M. 2006. Caracteres anatômicos de folha e caule de Calea uniflora Less., Asteraceae. Revista Brasileira de Farmacognosia 16: 53-60.

Cabrera, A.L. \& Ragonese, A.M. 1978. Revisión del género Pterocaulon (Compositae). Darwiniana 21: $185-257$.

Cancelli, R.R., Evaldt, A.C.P. \& Bauermann, S.G. 2007. Contribuição à morfologia polínica da família Asteraceae Martinov. no Rio Grande do Sul - parte I. Pesquisas, Botânica 58: 347-374.

Carlquist, S. 1958. Structure and ontogeny of glandular trichomes of Madinae (Compositae). American Journal of Botany 45: 675-682.

Carlquist, S. 1961. Comparative Anatomy. Holt Rienehart \& Winston, New York.

Castro, M.M., Leitão-Filho, H.F. \& Monteiro, W.R. 1997. Utilização de estruturas secretoras na identificação dos gêneros de Asteraceae de uma vegetação de cerrado. Revista Brasileira de Botânica 20: 163-174.

Cordeiro, C.A. \& Soares, L.C. 1977. A erosão nos solos arenosos da região sudoeste do Rio Grande do Sul. Revista Brasileira de Geografia 39: 82-150.

Cortadi, A., Sapio, O., Cargo, J.M., Scandizzi, A., Gattuso, S. \& Gattuso, M. 1999. Anatomical studies of Baccharis articulata, Baccharis crispa and Baccharis trimera, "carquejas" used in folk medicine. Pharmaceutical Biology 37: 357-365.

Costa, V.B.S., Almeida, G.M.A., Chagas, M.G.S. \& Pimentel, R.M.M. 2011. Indicadores anatômicos foliares como estratégias de defesa contra elevada incidência luminosa. Revista Brasileira de Geografia Física 4: 349-364.
Del-Vechio-Vieira, G., Barbosa, M.V.D., Lopes, B.C., Sousa, O.V., Santiago-Fernandes, L.D.R., Esteves, R.L. \& Kaplan, M.A.C. 2008. Caracterização morfoanatômica de Ageratum fastigiatum (Asteraceae). Revista Brasileira de Farmacognosia 18: 769-776.

Duarte, M.R., Budel, J.M., Matzenbacher, N.I. \& Menarim, D.O. 2011. Microscopic diagnosis of the leaf and stem of Lucilia nitens Less., Asteraceae. Latin American Journal of Pharmacy 30: 2070-2075.

Ehleringer, J.R. 1984. Intraspecific competitive effects on water relations, growth and reproduction in Encelia farinosa. Oecologia 63: 153-158.

Empinotti, C.B. 2005. Estudo anatômico foliar e caulinar de espécies medicinais de Asteraceae: Chaptalia nutans (L.) Pol., Elephantopus mollis Kunth e Tithonia diversifolia (Hemsl.) A. Gray. Dissertação de Mestrado, Universidade Federal do Paraná, Curitiba.

Empinotti, C.B. \& Duarte, M.R. 2008. Estudo anatômico de folha e caule de Elephantopus mollis Kunth (Asteraceae). Revista Brasileira de Farmacognosia 18: $108-116$

Evert, R.F. 2007. Esau's Plant anatomy: meristems, cells, and tissues of the plant body: their structure, function, and development. 3 ed. John Wiley \& Sons, Inc., Hoboken.

Faust, W.Z. \& Jones, S.B. 1973. The systematic value of trichome complements in a North American group of Vernonia (Compositae). Rhodora 75: 517-528.

Fernandes, A.C. \& Ritter, M.R. 2009. A família Asteraceae no Morro Santana, Porto Alegre, Rio Grande do Sul, Brasil. Revista Brasileira de Biociências 7: 395-439.

Fernandes, Y.S. 2014. Morfoanatomia, tricomas glandulares e análise fitoquímica de Trichogonia eupatorioides (Gardner) R.M. King \& H. Rob (Asteraceae-Eupatorieae) ocorrente em área de cerrado rupestre. Dissertação de Mestrado, Universidade Federal de Goiás, Goiânia.

Fernandes, Y.S., Trindade, L.M.P., Rezende, M.H., Paula, J.R. \& Gonçalves, L.A. 2016. Trichomes and chemical composition of the volatile oil of Trichogonia cinerea (Gardner) R. M. King \& H. Rob. (Eupatorieae, Asteraceae). Anais da Academia Brasileira de Ciências 88: 309-322.

Flora do Brasil 2020 (em construção). 2018. Asteraceae. Jardim Botânico do Rio de Janeiro. Available in http://floradobrasil.jbrj.gov.br/reflora/floradobrasil/ FB55 (access in 11-X-2017).

Franklin, G.L. 1945. Preparation of thin sections of synthetic resin and wood-resin composites, and a new macerating method for wood. Nature 155: 51.

Freire, S.E., Katinas, L. \& Sancho, G. 2002. Gochnatia (Asteraceae, Mutisieae) and the Gochnatia complex: taxonomic implications from morphology. Annals of the Missouri Botanical Garden 89: 524-550. 
Freitas, E.M., Boldrini, I.I., Müller, S.C. \& Verdum, R. 2009. Florística e fitossociologia da vegetação de um campo sujeito à arenização no sudoeste do Estado do Rio Grande do Sul, Brasil. Acta Botanica Brasilica 23: 414-426.

Freitas, E.M., Trevisan, R., Schneider, A.A. \& Boldrini, I.I. 2010. Floristic diversity in areas of sandy soil grasslands in Southwestern Rio Grande do Sul, Brazil. Revista Brasileira de Biociências 8: 112-130.

Funk, V.A., Susanna, A., Stuessy, T.F. \& Robinson, H. 2009. Classification of Compositae. In: V.A. Funk, A. Susanna, T.F. Stuessy \& R.J. Bayer (eds.). Systematics, Evolution, and Biogeography of Compositae. International Association for Plant Taxonomy, Vienna, pp. 171-189.

Hayat, M.Q., Ashraf, M., Khan, M.A., Yasmin, G., Shaheen, N. \& Jabeen, S. 2009. Diversity of foliar trichomes and their systematic implications in the genus Artemisia (Asteraceae). International Journal of Agriculture and Biology 11: 542-546.

Heiden, G., Barbieri, R.L., Wasum, R.A., Scur, L. \& Sartori, M. 2007. A família Asteraceae em São Mateus do Sul, Paraná. Revista Brasileira de Biociências 5: 249-251.

Heintzelman, C.E. \& Howard, R.A. 1948. The comparative morphology of the Icacinaceae. V. The pubescence and the crystals. American Journal of Botany 35: 42-52.

Hemenway, A.F. \& Allen, M.J. 1936. A study of the pubescence of Cacti. American Journal of Botany 23: 139-144.

Jana, B.K. 2014. Characterization of cypselar and anatomical parameter of some commonly occurring plants of Compositae in Kalyani, Nadia, West Bengal. International Journal of Innovative Research and Review 2: 20-28.

Johansen, D.A. 1940. Plant microtechnique. McGraw-Hill Book, New York.

Johnson, H.B. 1975. Plant pubescence: an ecological perspective. Botanical Review 41: 233-258.

Kaiser, E. 1880. Verfahren zur Herstellung einer tadellosen Glycerin-Gelatine. Botanisches Zentralblatt 180: 25-26.

Klamt, E. \& Schneider, P. 1995. Solos suscetíveis à erosão eólica e hídrica na região da Campanha do Rio Grande do Sul. Ciência \& Ambiente 11: 71-80.

Krak, K. \& Mráz, P. 2008. Trichomes in the tribe Lactuceae (Asteraceae) - taxonomic implications. Biologia 63: 616-630.

Kraus, J.E., Sousa, H.C., Rezende, M.H., Castro, N.M., Vecchi, C. \& Luque, R. 1998. Astra Blue and Basic Fuchsin Double Staining of Plant Materials. Biotechnic and Histochemistry 73: 235-243.

Levin, D.A. 1973. The role of trichomes in plant defense. The Quarterly Review of Biology 48: 3-15.
Lindman, C.A.M. \& Ferri, M.G. 1974. A vegetação no Rio Grande do Sul. Itatiaia, São Paulo.

Marchiori, J.N.C. 1995. Vegetação e areais no sudoeste rio-grandense. Ciência \& Ambiente 11: 81-92.

Martins, F.M. 2003. Estruturas secretoras da lâmina foliar de espécies de Senecio Tourn ex L. (Asteraceae). Tese de Doutorado, Universidade Federal de Viçosa, Viçosa.

Martins, L.R.R., Mourão, K.S.M., Albiero, A.L.M., Cortez, D.A.G., Dias-Filho, B.P. \& Nakamura, C.V. 2006. Estudo morfoanatômico preliminar do caule e da folha de Acanthospermum australe (Loefl.) Kuntze (Asteraceae-Heliantheae). Revista Brasileira de Farmacognosia 16: 42-52.

Melo-de-Pinna, G.F.A. 2004. Anatomia foliar de Richterago Kuntze (Mutisieae, Asteraceae). Acta Botanica Brasilica 18: 591-600.

Metcalfe, C.R. 1960. Anatomy of the monocotyledons. 1. Gramineae. Claredon Press, Oxford.

Metcalfe, C.R. \& Chalk, L. 1950. Anatomy of the dicotyledons. Claredon Press, Oxford.

Monteiro, W.R., Castro, M.M., Mazzoni-Viveiros, S.C. \& Mahlberg, P.G. 2001. Development and some histochemical aspects of foliar glandular trichomes of Stevia rebaudiana (Bert.) Bert. - Asteraceae. Revista Brasileira de Botânica 24: 349-357.

Moreno, J.A. 1961. Clima do Rio Grande do Sul. Boletim Geográfico do Rio Grande do Sul 11: 49-83.

Mussury, R.M., Betoni, R., Vieira, M.C., Scalon, S.D.P.Q. \& Barros, S.S.U. 2007. Morfo-anatomia do eixo vegetativo aéreo de Achyrocline alata (Kunth) DC. (Asteraceae). Revista Brasileira de Plantas Medicinais 9: 94-101.

Nakajima, J.N. \& Semir, J. 2001. Asteraceae do Parque Nacional da Serra da Canastra, Minas Gerais, Brasil. Revista Brasileira de Botânica 24: 471-478.

Narayana, B.M. 1979. Taxonomic value of trichomes in Vernonia Schreb. (Asteraeeae). Proceedings of the Indian Academy of Sciences - Section B. Part 2, Plant Sciences 88: 347-357.

Nimer, E. 1979. Climatologia do Brasil. IBGE Superintendência de Recursos Naturais e Meio Ambiente, Rio de Janeiro.

Oliveira, T., Bombo, A.B. \& Appezzato-da-Glória, B. 2013. Anatomy of vegetative organs with an emphasis on the secretory structures of two species of Aldama (Asteraceae-Heliantheae). Botany 91: 335-342.

Overbeck, G.E., Boldrini, I.I., Carmo, M.R.B., Garcia, E.N., Moro, R.S., Pinto, C.E., Trevisan, R. \& Zannin, A. 2015. Fisionomia dos Campos. In: V.P. Pillar \& O. Lange (eds.). Os campos do Sul. Rede Campos Sulinos UFRGS, Porto Alegre, pp. 33-41.

Overbeck, G.E., Müller, S.C., Fidelis, A., Pfadenhauer, J., Pillar, V.D., Blanco, C.C., Boldrini, I.I., Both, R. \& Forneck, E.D. 2007. Brazil's neglected biome: The South Brazilian Campos. Perspectives in Plant Ecology, Evolution and Systematics 9: 101-116. 
Panero, J.L., Freire, S.E., Espinar, L.A., Crozier, B.S., Barboza, G.E. \& Cantero, J.J. 2014. Resolution of deep nodes yields an improved backbone phylogeny and a new basal lineage to study early evolution of Asteraceae. Molecular Phylogenetics and Evolution 80: 43-53.

Payne, W.W. 1978. A glossary of plant hair terminilogy. Brittonia 30: 239-255.

Perveen, A., Khan, M., Mansuri, S. \& Tabassum, T. 2016. Morphological studies on trichome of family Asteraceae. International Journal of Biology and Biotechnology 13: 177-182.

Ramayya, N. 1962. Studies on the trichomes of some Compositae I. General structure. The Bulletin of the Botanical Survey of India 4: 177-188.

Redonda-Martínez, R., Villaseñor, J.L. \& Terrazas, T. 2012. Trichome diversity in the Vernonieae (Asteraceae) of Mexico I: Vernonanthura and Vernonia (Vernoniinae). Journal of the Torrey Botanical Society 139: 235-247.

Redonda-Martínez, R., Villaseñor, J.L. \& Terrazas, T. 2016. Trichome diversity in the subtribe Leiboldiinae (Vernonieae, Asteraceae). Journal of the Torrey Botanical Society 143: 298-310.

Ritter, M.R. \& Baptista, L.R.M. 2005. Levantamento florístico da família Asteraceae na "Casa de Pedra" e áreas adjacentes, Bagé, Rio Grande do Sul. Iheringia, Série Botânica 60: 5-10.

Rojas-Leal, A., Villaseñor, J.L. \& Terrazas, T. 2017. Tricomas foliares en Senecio sección Mulgediifolii (Senecioneae, Asteraceae). Acta Botanica Mexicana 119: 69-78.

Roque, N. \& Bautista, H. 2008. Asteraceae: caracterização e morfologia floral. EDUFBA, Salvador.

Saha, L. \& Mukherjee, S.K. 2012. Morphological variation of trichomes in some common species of Asteraceae. International Journal of Pharmaceutical Research and Bio-Science 1: 408-425.

Sancho, G., Hind, D.J.N. \& Pruski, J.F. 2010. Systematics of Podocoma (Asteraceae: Astereae): a generic reassessment. Botanical Journal of the Linnean Society 163: 486-513.

Santos, V.S. 2013. Morfoanatomia dos órgãos vegetativos de Chrysolaena simplex (Less) Dematt. e Lessingianthus buddleiifolius (Mart. ex DC.) H. Rob. (Asteraceae) em ambientes rupestres da Serra Dourada, Goiás. Dissertação de Mestrado, Universidade Federal de Goiás, Goiânia.
Smiljanic, K.B.A. 2005. Anatomia foliar de espécies de Asteraceae de um afloramento rochoso no Parque Estadual da Serra do Brigadeiro (MG). Tese de Doutorado, Universidade Federal de Viçosa, Viçosa.

Solereder, H. 1908. Systematic Anatomy of the Dicotyledons. Clerendon Press, Oxford.

Sosa, M.M., Pico, G.M.V. \& Dematteis, M. 2014. Comparative anatomy of leaves and stems in some species of the South American genus Chrysolaena (Vernonieae, Asteraceae) and taxonomic implications. Nordic Journal of Botany 32: 611-619.

Streck, E.V., Kämpf, N., Dalmolin, R.S.D., Klamt, E., Nascimento, P.C., Schneider, P., Giasson, E. \& Pinto, L.F.S. 2008. Solos do Rio Grande do Sul. 2 ed. EMATER/RS, Porto Alegre.

Sulborska, A. 2013. Structure and distribution of glandular and non-glandular trichomes on above-ground organs in Inula helenium L. (Asteraceae). Acta Agrobotanica 66: 25-34.

Trindade, L.M.P. 2013. Morfoanatomia, tricomas glandulares 'e fitoquímica de Lomatozona artemisiifolia Baker (Asteraceae - Eupatorieae) - uma planta endêmica do cerrado de Goiás. Dissertação de Mestrado, Universidade Federal de Goiás, Goiânia.

Trindade, L.M.P., Fernandes, Y.S. \& GonçalveS, L.A. 2014. Diversidade e desenvolvimento dos tricomas glandulares de Lomatozona artemisiifolia Baker (Asteraceae - Eupatorieae) - uma planta endêmica do Cerrado de Goiás. Iheringia, Série Botânica 69: 235-243.

Verdum, R. 2004. Depressão periférica e planalto: potencial ecológico e utilização social da natureza. In: R. Verdum, L.A. Basso \& D.M.A. Suertegaray (orgs.). Rio Grande do Sul: paisagens e territórios em transformação. Editora da UFRGS, Porto Alegre, pp. 39-57.

Wagner, G.J. 1991. Secreting glandular trichomes: more than just hairs. Plant Physiology 96: 675-679.

Wagner, G.J., Wang, E. \& Shepherd, R.W. 2004. New approaches for studying and exploiting an old protuberance, the plant trichome. Annals of Botany 93: 3-11.

Wagner, M.A., Loeuille, B.F.P., Siniscalchi, C.M., Melode-Pinna, G.F. \& Pirani, J.R. 2014. Diversity of non-glandular trichomes in subtribe Lychnophorinae (Asteraceae: Vernonieae) and taxonomic implications. Plant Systematics and Evolution 300: 1219-1233.

Wang, H., Shi, H. \& Wang, Y. 2015. The wetting of leaf surfaces and its ecological significances. In: M. Aliofkhazraei (ed.). Wetting and Wettability. InTech, London, pp. 295-321.

Werker, E. 2000. Trichome diversity and development. Advances in Botanical Research 31: 1-35. 